in recent years that the new mathematical logic has had any impact on librarianship; and now there is no going back. The Classification Research Group in England and this book of Vickery's do not contribute to nor advance towards a unified theory of information retrieval; rather, they represent an antiscientific obscurantism which is defending tradition against scientific and logical advance.-Mortimer Taube, Documentation, Inc.

\section{Music Librarianship}

Music Librarianship, a Practical Guide. By Eric Thomas Bryant. London: James Clarke, 1959; New York: Hafner, 1959. 503p. $\$ 6.50$.

The first book on music librarianship to appear since McColvin and Reeves published their basic guide over twenty years ago should have been greeted with cries of joy. With the development of so many new music collections in libraries during that period, the time was certainly ripe for an up-to-date volume on the subject. This latest effort, however, should not deter aspiring authors who might have been considering a publication similar to this one.

Mr. Bryant is the borough librarian of Widnes, Lancashire, and according to his introductory remarks, the book "was written primarily for public librarians and their assistants, and from a British standpoint." The latter phrase was most timely and wise and should serve Mr. Bryant as some form of protection against the ire of American reviewers and readers.

His American sources, other than correspondence, included the $A L A$ Bulletin, $L i$ brary Journal, student theses from Kent State University and the University of Chicago, and the Public Library Inquiry volume on music which was written by Otto Luening. More detailed checking of data might have spared Mr. Bryant some future headaches as well as rid him of some of his headstrong ideas. The Harold Barlow of the Barlow and Morgenstern Dictionaries of Musical Themes is not an American conductor whose $78 \mathrm{rpm}$ recordings have ap- peared in England, but Howard Barlow is. Also, a more careful proof-reading might have led to the discovery that Luening's first name of Otto is used correctly four times but appears once as Oscar.

The volume is divided into two parts. The first deals with administration, reference books and periodicals, cataloging, classification, gramophone record libraries, and an appendix containing a rather forlorn list of subject headings. Part two is given over to a graded list of instrumental and vocal music, miniature scores, and three supplementary sections, including an index to the works listed in this part, music publishers and their English agents, and instrumental tutors.

The sections on cataloging and classification are given in great detail and with copious examples. The classification systems outlined are Brown's Subject, the Cutter Expansive, the Dewey Decimal, the Library of Congress, Bliss' Bibliographic, and the British Catalogue of Music. The author states that all of these sections have been checked by experts, including Bliss who, before his death, read the first two drafts of the discussion of his system. Bryant also points out that any opinions expressed are his own. A helpful chart at the end of the chapter shows clearly how fifteen scores and books would be classed in each of the systems.

Mr. Bryant does doff his hat slightly several times to American librarianship for its cataloging codes, its many publications in books and journals on the various facets of organizing and maintaining music collections, and he also deplores the lack of people in Britain to make up an organization such as the American Music Library Association. I expect that he will receive some replies to his statement that "the American record user is apparently tending to become more interested in the actual work recorded and to pay less attention to the particular artist; the assumption is growing that any orchestra, soloist, etc., that is good enough to achieve a contract wath a gramophone record manufacturer must be competent." In the light of such a bold and also erroneous statement I wonder how Mr. Bryant would explain the works currently available that have twenty or more different recorded performances, and why the American record reviewers consistently point out the differences between A's performance as contrasted with B's and why 
consumers purchase the A performance rather than the $\mathbf{B}$ performance of the same work.

British librarians, in general, and $\mathrm{Mr}$. Bryant, in particular, seem to have one soulsearching problem and that is the cataloging of the "recital" disc, for he speaks of it often. American librarians have found a rather simple remedy for this and similar problems by using extended added entries. I am sure that any American librarian would have been only too happy to help with this solution if the invitation had been offered. The entire chapter on recordings is garrulous beyond endurance with overly detailed comments on all phases of the work from selection to withdrawal. Isn't it about time that libraries, with the exception of the major archival types, face the fact that recordings are ephemeral materials and treat them as such? Readers accustomed to our generous lending policies might be horrified to learn that one English library actually sends a staff member to check the playing equipment in the borrower's home before a record borrowing permit is issued, and that after a certain period of time the borrower must show a receipt to prove that he has purchased a replacement for his cartridge or stylus.

Mr. Bryant has evidently put a great deal of thought and effort into this volume and the fact that it has been in progress for quite some time is evident from his statement concerning the Angel DeLuxe packaging, which has not been available for more than a year. He also mentions that a study on the preservation of recordings is "about to be undertaken" by the Library of Congress. This study was completed and published as of October 1959.

Following the pattern of McColvin and Reeves and other authors on the subject, the second half comprises lists of recommended scores graded $\mathrm{A}$ to $\mathrm{E}$ and signifying materials to be included in A, the smallest independent library, and moving progressively to $\mathrm{E}$, the largest collection. The ideas expressed in these lists are rather strange in contrast to an earlier remark that only music heard in concerts or available on records should be the basis for purchasing. Furthermore, for the more adventurous there is the stern warning to "withdraw or do not buy works by composers who rate but a few lines in Grove's Dictionary or do not appear there." Grove, in addition to being very pro-British, is slightly dated at this point, having been published in 1954, and even then was not entirely free from errors of omission! A random sampling of the opera scores in the graded lists shows that the smallest library would be likely to have a fairly representative collection of the popular repertory as well as Britten's Peter Grimes, Gay's Beggar's Opera, and two scores by Edward German, Merrie England and Tom Jones, as well as all the Gilbert and Sullivan scores. Only the largest collection would be able to supply a reader with a copy of Wozzeck, Louise, Martha, Andrea Chenier, Parsifal, and Salome!

Mr. Bryant does give credit to America for "its musicals that have far greater vitality than the home-grown specimens. The King and $I$ and $M y$ Fair Lady are more recent examples of American successes (though with some British collaboration)."

Altogether, Mr. Bryant has written a book which should prove helpful to the newer British libraries being formed as well as to those which are already in existence. The "matters of interest and use that librarians overseas will find in it" will probably be restricted mainly to purposes of comparison, and wonderment over the extremely biased and chauvinistic attitude displayed throughout and without apparent reason.-Thomas T. Watkins, Music Library, Columbia University.

\section{Cataloging Persian Books}

\section{Cataloging of Persian Works; Including} Rules for Transliteration, Entry and Description. By Nasser Sharify. Chicago: ALA, 1959. 161 p. \$3.50.

For centuries, libraries in the Middle East were storehouses-safe-deposit buildings for books and manuscripts. Their sole function was to protect their valuables but to discourage their use. Standard cataloging codes, uniformity in author entries, and other accepted practices of present-day libraries were unknown. Every library had its own particular system for recording the material it housed, but that system was not devised with service to the user principally in view.

When libraries began to be used by the people, they ceased to function merely as 